\title{
Bir Muhasebe Meslek Odasında 2008-2013 Yıllarında Verilen Disiplin Cezalarının Yapısal Analizi
}

\author{
Selahattin KARABINAR * \\ Zülküf ÇEVIK **
}

\begin{abstract}
ÖZET
Dünyada muhasebe meslek örgütleri, mesleğin itibarını ve mesleki davranışların yüksek standartlarını korumayı amaç edinmiştir ve bu sebeple yönetmelikler ve tebliğler yoluyla düzenlemeler yapmaktadırlar. Bu çalışmanın amacı, meslek örgütünün yerel teşkilatlanması olan meslek odaları tarafindan, yönetmelikler çerçevesinde 2008-2013 yılları arasında verilen disiplin cezalarını incelemektir. Bu amaçla, bir SMMM odasının vermiş olduğu disiplin cezalarının türü ve hangi etik yaklaşımına aykırı olduğu örnek vakalar üzerinden incelenmiştir.
\end{abstract}

Anahtar Kelimeler: Muhasebe Meslek Etiği, Disiplin Cezalart.

JEL Sınıflandırması: M41, M19.

The Structural Analysis of Disciplinary Penalties Given by a Certified Public Accountants' Chamber between the Years 2008-2013

\section{ABSTRACT}

The accounting profession organizations in all over the world have a goal of upholding the dignity and honor of the accounting profession, and maintain high standards of professional conduct by using professional regulations and communiqués. The purpose of this study is to investigate disciplinary punishment, which given by the CPA chambers, between the years of 2008-2013. For this purpose, disciplinary penalties which given by a CPA Chamber have been examined by its type and ethical philosophy.

Keywords: Accounting Profession Ethics, Disciplinary Penalties.

Jel Classification: M41, M19.

\footnotetext{
* Prof. Dr. Selahattin Karabınar, İstanbul Üniversitesi, İktisat Fakültesi, selahattin.karabinar@istanbul.edu.tr

** Dr. Zülküf Çevik, Sakarya Üniversitesi, İşletme Fakültesi, zcevik@sakarya.edu.tr
} 


\section{GİRIŞ}

Bir meslek olarak muhasebe, diğer mesleklerden, taşıdığı sorumluluk açısından farklılaşmaktadır. Muhasebe mesleğini icra eden meslek mensupları yapmış olduğu faaliyetlerinden ötürü sadece müşterilerine karşı sorumlu değil aynı zamanda işletmenin hissedarlarına, kredi verenlere, devlete ve hatta topluma karşı sorumludur. Bu sorumluluk çoğu kez meslek mensuplarını etik ikilemler ile karşı karşıya bırakmaktadır. Böyle durumlarda meslek mensuplarının nasıl davranmaları gerektiği yasa koyucular ve meslek örgütleri tarafından zorunlu meslek kuralları adı altında genel olarak belirlenmiştir.

Geçmişte yaşanan muhasebe skandalları meslek etiği konularını tekrar gündeme getirmiş olmasına rağmen muhasebe mesleğinin gelmiş olduğu noktada, meslek etiği tartışmaları kısmen de olsa meslek mensupları arasında çözüme kavuşturulmaya çalışılmıştır. Yaşanan ekonomik, sosyal, yasal ve politik olayların birçoğu meslek mensuplarının davranışları ve faaliyetleri üzerinde etkili olsa da son yıllarda ağırlığını daha fazla hissettiren konu, kamunun meslek mensuplarından artış gösteren beklentileri olmuştur (Frankel, 1989).

Muhasebe meslek mensupları ve muhasebe kurumları her geçen gün artan kamu denetimine maruz kalmaktadır (Lee, 1995;48). Meslek mensubunun mesleki faaliyetlerini düzenleyici yasalar genel manada kamu yararını sağlamayı amaçlamaktadır. Kamu, çoğu zaman sunulan profesyonel hizmetin kalitesini ölçemez. Lakin sunulan bir hizmetin ismi önünde profesyonel başlı̆̆ (unvanı) geldiğinde bu hizmete güvenebileceğimiz hususunda kamuda haklı ve büyük bir beklenti oluştuğu da bir gerçektir. Aynı şekilde, bir mesleğin mensupları bir bütün olarak mesleğin itibarını korumak istemeleri, uzun vadede bireysel çıkarlarını koruma içgüdüsünün güçlü bir tezahürüdür. Diğer bir deyişle, bir mesleğin mensupları bireysel çıkarlarını uzun vadede koruyarak bir bütün olarak mesleğin itibarını korumuş olmaktadır (Canning \& O'Dwyer , 2001). Dolayısıyla, kamunun profesyonel hizmeti ölçememesine rağmen profesyonellerden beklediği güvenli hizmet ve meslek mensubunun da uzun vadede mesleğin itibarını koruma isteği kamusal ve özel çıkarlar arasında bir uyumun olduğunu gösterir. Mesleki standartların hazırlanması ve korunması açısından bu uyumun dengeleyici bir unsur olduğu düşünülebilir.

Muhasebe mesleğinin itibarını korumak ve olabilecek en iyi seviyeye yükseltmek için uluslararası ve yerel kuruluşlar faaliyette bulunmaktadır. Uluslararası Muhasebeciler Federasyonu (IFAC) uluslararası anlamda bu faaliyetleri yürütürken, Amerika'da Amerikan Kamu Muhasebecileri Enstitüsü (AICPA), Türkiye'de ise Türkiye Serbest Muhasebeci Mali Müşavirler ve Yeminli Mali Müşavirler Odaları Birliği (TÜRMOB) bu görevi üstlenmektedir. Mesleğin itibarının korunması ve yükseltilmesine yönelik olarak çalışan bu kurumlar aynı zamanda meslek etiğinin sürdürülebilirliğinin sağlanması için bir takım cezai müeyyideler uygulamaktadir.

$\mathrm{Bu}$ çalışmada, muhasebe mesleğinin etik yönünü düzenleyici kanun, yönetmelik ve genelgelere değinilerek, disiplin suçunu gerektiren davranışların neler olabileceği hususunda bir meslek odası tarafindan 2008-2013 döneminde verilen disiplin cezaları incelenmiştir. Çalışmanın amacı, meslek mensupları tarafından gerçekleştirilen meslek kurallarına uygun olmayan davranışları (ki bunların birçoğu etik de değildir) Ahlak felsefesi açısından incelemektir. 


\section{LITERATÜR TARAMASI}

Muhasebe mesleği ve meslek etiği birçok araştırmaya konu edilmekle birlikte, meslek etiğini yakından ilgilendiren mesleğe ait disiplin cezalarının etik yönü hususunda çok fazla çalışma bulunmamaktadır. Konunun derinlemesine ele alınabilmesi için öncelikle muhasebe mesleği ve etiği konularında yapılmış olan çalışmaların bir kısmı bu bölümde ele alınacaktır.

Mitchell ve diğerleri (1994) tarafından yapılmış bir çalışmada, İngiltere'de muhasebe firmaları ve ortakları tarafından gerçekleştirilen denetim hatalarını ve meslek kurallarına/ahlakına aykırı faaliyetlerine dair ortaya atılan iddiaların geçerliliğini, mesleki pozisyona göre ölçmeyi amaçlamıştır. Yazarlara göre, mükemmel bir dünyada yaşıyor olsaydık mesleği icra edenler, müşterilerinin ve kendi çıkarlarını bir kenara bırakarak, sadece toplumun (kamunun) çıkarlarını göz önüne bulundurarak mesleklerini icra ederlerdi. Fakat, mükemmel bir dünyada değil, çıkar çatışmalarının, pazar baskısının ve rekabetin yüksek olduğu bir dünyada, öyle ki düzenleyici kurumların bile kendi çıkarlarını ortaya koyduğu bir dünyada yaşıyoruz. Bu nedenle, bu kadar yakın ve eleştirel denetlemeye tabi bir sektörün kamu yararını tam ve etkin olarak dile getirmek ve korumak için devletin kaynaklarını ve gücünü kullanarak bağımsız bir düzenleme yapmak suretiyle bağımlı düzenlemeleri kaldırması gerektiği sonucuna varılmıştır.

Parker (1987) ise, Avusturalya'da 1885-1983 yılları arasında meslek etiği standartlarının oluşumu, muhasebe mesleğinin etik standartlar açısından gelişimini ve doğasına etki eden faktörleri incelemiştir. Sonuç olarak Parker, mesleğin korunması için ortaya atılan ve üzerinde durulan birçok etik mevzunun aslında toplumu korumak için daha önceden kabul görmüş ve yayınlanmış etik problemler olduğu kanısına varmıştır.

Garmilis ve Stokes (2007) ise, uygulamalar açısından son derece farklılık gösterdiği kabul edilen $A B D$ ve Fransa'nın muhasebe mesleği için uygulamada olan disiplin işlemlerinin karşılaştırmasını yapmıştır. Bu çalışmada, Yasalcılık'ın (Legalism) Amerika muhasebe mesleği disiplin işlemlerinin önemli bir bölümünü oluşturduğunu ve yapılan diğer çalışmaların aksine Fransa ile ABD'nin meslek düzenlemelerinde devletin gücünün etkisi açısından birbirlerine çok benzedikleri kanısına varmışlardır. Ayrıca disiplin işlemleri sonucunu gözlemlediklerinde ise yine iki ülkenin uygulamalarının birbirlerine çok yakın olduğu ve disiplin işlemlerinin çok katı olmadığı görülmüş̧ür. Öyle ki, meslek mensuplarının çok büyük bir kısmına zarar vermeyecek nitelikte olan disiplin işlemleri ve meslek ile ilgili disiplin kuralları yaptırımlarının çok küçük bir meslek mensuplarına verildiği sonucuna varmışlardır.

Garmilis ve Stokes'un çalışmasına benzer bir çalışma da Baker, Bedard ve Prat Dit Hauret tarafından yapılmıştır. Baker ve diğerlerinin (2005) çalışmasında ABD ve Fransa arasındaki muhasebe mesleği düzenlemelerindeki farklılıklar incelenmiştir. Amerika'da meslek ile ilgili düzenlemelerin baskın modeli, Çağrışımcılık ${ }^{*}$ (Associationism) ve Yasalcılık

\footnotetext{
*Çağrışımcılık: “Bütün bellek işlemlerini, aklın bütün ilkelerini hatta bellek hayatının hepsini, düşüncelerin çăgrışımı ile açıklamak isteyen öğreti” Kaynak: TDK, www.tdk.gov.tr, Erişim: 12.12.2013.
} 
(Legalism) $^{* *}$ karışımıyla domine olmuşken, Fransa'da Kurumsalcılık (Corporatism) ${ }^{* * *}$ ve Yasalcılığın bir karışımının etkili olduğu sonucuna varılmıştır.

Bedard (2001), muhasebe mesleği disiplin işlemlerinin (sürecinin) mesleği mi, yoksa kamuyu mu (toplumu) korumaya yönelik olduğuyla ilgili yapmış olduğu çalışmasında, Kanada'nın doğu eyaletinin yetki alanı içerisinde kamu yararını korumada muhasebe mesleğindeki disiplin faaliyetlerinin rolü incelenmiştir. Bu çalışmada, muhasebe meslek kurallarının yine mesleğin mensupları tarafından düzenlenmesine (self-regulatory) rağmen birçok kuralın devletin baskısı, halkın zorunlu katılımı ve yasa koyucu bir kurum tarafından gözetiminin yapıldığ1 bir yapı/mevcut durum söz konusudur. Dava aşamasındaki disiplin işlemlerinin, katı bir şekilde düzenlenen halkın katılımının yüksek olduğu kamu yararı ihlallerinin baskın olması, özel (bireysel) çıkarlarının ihlallerinden çok daha ciddi olduğu kanısına varılmıştır. Takdir yetkisinin yüksek, halk katılımının düşük olduğu sorgulama aşamasında ise davayı açıp açmama kararının disiplin sürecinin (işlemlerinin) maliyetine, davanın kötü (olumsuz) şöhretine ve dava sonucunun suçsuzluk hükmüne varılması riskine bağlı olarak verildiği sonucuna varılmıştır. Özetle, Muhasebe mesleği disiplin işlemlerinde kamu yararının (çıkarının), özel (bireysel) çıkarları domine etmesi, ilgili davaya (olaya) halkın katılım ve yasal düzenleme (regulation) derecesine göre değişmektedir.

Ülkemizde ise, meslek mensuplarına verilen disiplin cezalarının Resmi Gazete'de yayınlananları (geçici olarak mesleki faaliyetten men ve meslekten men cezaları) 2000-2008 dönemi Banar ve Aslan (2009) tarafindan incelenerek, mükellef türü ve sayısı, muhasebe meslek mensubu türü ve sayısı bağımsız değişkenlerinin bu cezalar üzerinde etkisinin olup olmadığı araştırılmıştır. Araştırma sonucunu kısaca özetleyecek olursak, meslek mensuplarının belirtilen bağımsız değişkenlerden mükellef türüne (GV-KV mükellefi) ve sayısına göre cezalarla arasında ilişki olduğu ve Türkiye'de en fazla gelir vergisi mükellefi olduğu sonucuna varılmıştır. Benzer bir çalışma da Ekergil (2016) tarafından gerçekleştirilen ve 1993-2015 yılları arasındaki Resmi Gazetede yayımlan disiplin cezalarını meslek mensuplarının unvan, disiplin cezası türleri, cinsiyet, coğrafi bölgeler ile tek ve birden fazla ceza verilen meslek mensupları değişkenleri üzerinden incelenmiştir. Bu araştırmanın sonucunda, incelenen dönemde en fazla disiplin cezası sayısı Serbest Muhasebecilerin aldığı, ceza sayısı Marmara bölgesinin bölgesel olarak en büyük paya sahip olduğu, kadınların disiplin cezaları sayısı ve meslek mensupları sayısı bakımından çok az sayıda olduğu belirtilmiştir.

Muhasebe meslek mensuplarına verilen disiplin cezaları ile ilgili yapılan bir diğer çalışmada ise Türkiye'deki meslek mensuplarına mesleki kurallara duyarlılığı resmi gazetede yayımlanan meslek mensuplarına verilmiş disiplin cezaları yardımlıyla cinsiyet yönünden karşılaştırılmıştır (Yaşar, 2016). Çalışmanın sonucuna göre erkek meslek mensuplarının kadın meslektaşlarına göre daha fazla sayıda disiplin cezası aldıkları bunun sonucunda da

Çağrışımcılık (Associationism) öğretisi, Baker ve diğerlerinin (2005) çalışmasında “Düzenleyici faaliyetler, meslek örgütleri tarafindan üyelerinin çıkarlarını temsil etmek ve korumak için yürürlüğe konurlar” şeklinde tanımlanmıştır.

***Kurumsalcılık (Corporatism): “Devlet, meslek örgütlerinin sadece kurulmasına izin vermez, aynı zamanda onların düzenleyici faaliyetlerinin içine entegre olur/bütünleşir” (Baker C. R.ve diğerleri, 2005; 4-5).

**** Yasalcılı (Legalism): “Düzenleyici faaliyetlerin, düzenleyici gücün devletin elinde bulunduğu ve devlet tarafından yayımlanan kanun ve düzenlemelere uygun olarak gerçekleştirilmesidir” (Baker C. R.ve diğerleri, 2005; 4-5). 
kadın meslek mensuplarının mesleki kurallara duyarlılığının erkek meslek mensuplarından daha fazla olduğu belirtilmiştir (Yaşar, 2016). Gül (2016) ise çalışmasında meslek mensuplarının 2001-2015 döneminde almış olduğu disiplin cezalarını kayıtlı olunan oda, unvan ve cinsiyet kategorilerine göre değişimini incelemiştir. Muhasebe meslek mensuplarının aldığı disiplin cezalarının yıllar itibariyle sayısal gelişimi ile muhasebe meslek mensuplarının yıllar itibariyle sayısal gelişiminin paralellik göstermediği ve cinsiyete göre bakıldığında erkek meslek mensuplarının oransal olarak kadın meslektaşlarından daha fazla disiplin cezası aldığı çalışmanın sonucunda belirtilmiştir (Gül, 2016). Ülkemizde yapılan muhasebe meslek mensuplarına verilen disiplin cezaları genel olarak Resmi Gazetede yayımlanan veriler üzerinden incelenmiştir. $\mathrm{Bu}$ veriler meslek mensubunun demografik özelliklerine ve kayıtlı olunun odanın bölgesine göre sınıflandırmalar yapılmıştır.

$\mathrm{Bu}$ çalışmada da muhasebe meslek mensuplarının mesleki davranışlarını düzenleyen disiplin mevzuatı ve bu mevzuatla ilişkili olarak meslek mensuplarının etik olmayan davranışlarının incelenmesi ve bu cezaları etik filozoflarının yaklaşımları açısından değerlendirilmesi amaç edinilmiştir.

\section{MUHASEBE MESLEK ETİĞİ DÜZENLEMELERININN FELSEFi DAYANAĞI}

Meslek mensubunun uyması gereken bir disiplin yönetmeliğinin olması neden gereklidir? Yönetmelikler olmazsa meslek vakar ve onuru korunamaz mı? Bu ve buna benzer soruları arttırmak mümkündür. Birçok meslekte olduğu gibi muhasebe mesleğinde de meslek mensubunun uymak zorunda olduğu bir takım mevzuat söz konusudur. Mevzuat belli bir takım amaçlar doğrultusunda çıkarılmaktadır. Bu amaçlardan biri de "tüm üyeleri (...), sosyal sorumluluk bilinci olan, etik değerlere bağl1, (...), güvenilir ve saygın bir meslek mensupları kitlesi oluşturmak hedefine ulaşmayı” (Serbest Muhasebeci Mali Müşavirler ve Yeminli Mali Müşavirlerin Mesleki Faaliyetlerinde Uyacakları Etik İlkeler Hakkında Yönetmelik, 2007) hedeflemektedir. Kısacası, meslek mevzuatı ile mesleği korumak ve meslek mensubuna yakışmayacak hal ve davranışları engellemek amaçlanmaktadır.

Yukarıdaki sorulara çeşitli etik fillozoflarının yaklaşımları ile cevap aramak üzere aşağıda değişik etik yaklaşımlar ele alınmıştır. Açıklanan etik yaklaşımlar sonucunda muhasebe mesleğini düzenleyici faaliyetlerin mevcut olmasının gerekliliği hususunda etik yaklaşımlardan çıkarsamalar yapılarak yazar görüşü belirtilecektir.

\subsection{Durkheim ve Plato'da Etik}

Plato'nun, Devlet adlı eserinde geçen bir hikâyede Gyges adlı Lydialı bir çobanın bulmuş olduğu yüzükle görünmez olduktan sonra yapmış olduğu eylemler anlatılmaktadır*.

\footnotetext{
* Hikâyeye göre, Gyges, Lidya kralının hizmetinde bir çobandır. Günün birinde bir kasırga veya deprem yüzünden yer çatlar ve hayvanların otladığı yerde derin bir yarık açılır. Bu yarığın içine inen çoban, orada içi oyuk, üstü delik deşik, tunçtan bir at bulur. Eğilip atın içine baktığında orada insan boyundan büyük, parmağındaki altın bir yüzük olan ölü görür. Bu yüzüğü alıp yukarı çıkar. Çobanlar ay sonunda krala hesap vermek için toplanırlarmış. Gyges toplantıya bu yüzükle gelir. Otururken yüzüğün taşını farkına varmadan avucunun içine çevirir. Bunu yapar yapmaz da görünmez olur. Kendisi de dâhil, orada bulunan herkes şaşakalır. Yüzükle oynarken taşı çevirince yine görünür olur. Böylece Gyges, yüzüğün tılsımını keşfeder: Yüzüğün taşını
} 
Aynı yüzükten olsa hangi eylemleri gerçekleştirirdim? şeklinde düşünüldüğünde kendi kendimize verdiğimiz cevap acaba ne olurdu? Elimizde böyle iki yüzük olsa ve birini doğru olarak gördügümüz adamın, diğerini eğri adamın parmağına taktığımızda, ikisinin de davranışı bir olacaktır. Çünkü bu durumda hiç kimse, doğruluğa bağlı kalarak, başkalarının malına el sürmeyecek kadar babayiğit olamaz. Platon'un bu örneği insanın kendi isteğiyle değil, zorlanarak etik davrandığını gösterir (Platon, 2001; 360).

$\mathrm{Bu}$ görüşe göre, hiç kimse, zorunda değilse, etik davranış sergilemez. Bu toplum içerisinde yaşayabilmemiz için ödemek zorunda olduğumuz bir bedel, oynamak zorunda olduğumuz karmaşık bir oyundur. Ahlak, uyulmak zorunda olunan kurallar seti ve bireyin yapmak istedikleri davranışlar karşısında duran güçlü bir yoldur. Eğer güçlü insanlar yaptıkları yüzünden suçluluk duygusuyla beyinleri yıkanmasa, bu tür insanlar ne isterlerse onu yaparlar. Gerçekten endişe duyulmaya değer tek kural vardır: Yakalanmamak (Horner ve Westacott, 2000;151).

$\mathrm{Bu}$ bakış açısı ile değerlendirildiğinde, insanlara dilediklerini yapma fursatı verildiğinde doğrunun gittiği yer, eğrinin gittiği yer olacaktır. Çünkü kendinde olandan daha fazla şey istemek, insanın yaradılışında olan bir şeydir. Dolayısıyla, insanları kötü olarak nitelendirilen şeylerden alıkoymak ancak onların üstünde bir otorite tarafından (kanunla) mümkün olacaktır (Platon, 2001; 359). Burada sözü geçen "kanun" kelimesi dar anlamıyla ilk akla gelen yasa kelimesinin yanı sıra farklı anlamlar da taşımaktadır. Örneğin, din kuralları, kültürel inanışlar, toplumsal değerler, kısacası insanı doğruya yöneltmeyi hedefleyen tüm normlar.

Durkheim'in (1986), Meslek Ahlakı (La Morale Professionnelle) isimli eserinde ifade ettiği gibi bir toplumsal kurum, bir ahlak disiplini olmadan yaşayamaz. Aksi durumda bu kurum ancak birbirleriyle çatışma içinde olan fertler topluluğuna dönüşür. Platon'un belirtilen görüşleri doğrultusunda, insanoğlu yaradılışı gereği kimi zaman hakkı olmadığı ya da doğru olmayan eylemler içine girmeye meyillidir. İnsanları bu eylemlerden alıkoymak için din, kültür, toplumsal değerler vb. tek başına yeterli olmayabilir. Bu sebepledir ki kanunlar, kurallar, yönetmelikler aracılığı ile belirtilen cezalarla, insanlar doğru olmayan davranışları sergilemekten alıkonulmaya çalışılmaktadır.

\subsection{Normatif Etik Teoriler}

Normatif etik teorilerin temel sınıflandırılması: Teleolojik etik (sonuçsalçı), Deontolojik etik ve Erdem etiği şeklinde yapılmaktadır (Jonsson, 2011) (Belak \& Rozman, 2012) (Whetstone, 2001) (Hartman \& DesJardins, 2011). Normatif teoriler belli bir durum hakkında yapılacak eylemler ile ilgili yol gösteren, eylemin iyi-kötü, doğru-yanlış ya da yükümlülük olup olmadığı ile ilgili yargıda bulunmayı sağlayan yaklaşımlardır (Kart, 2006, s. 52). Bu çalışmada Normatif etik teorilerden kısaca bahsedilerek çalışmanın amacı doğrultusunda analiz edilen disiplin cezalarının bu etik yaklaşımlarla ilişkisi tespit edilmeye

içeri çevirince görünmez oluyor, düzeltince görünür. Bunun üzerine görünmez olarak saraya girer, sarayda kraliçeyi baştan çıkartır, onun yardımıyla kralı öldürüp yerine geçer (Devlet, 2001; 359). 
çalışılacaktır.

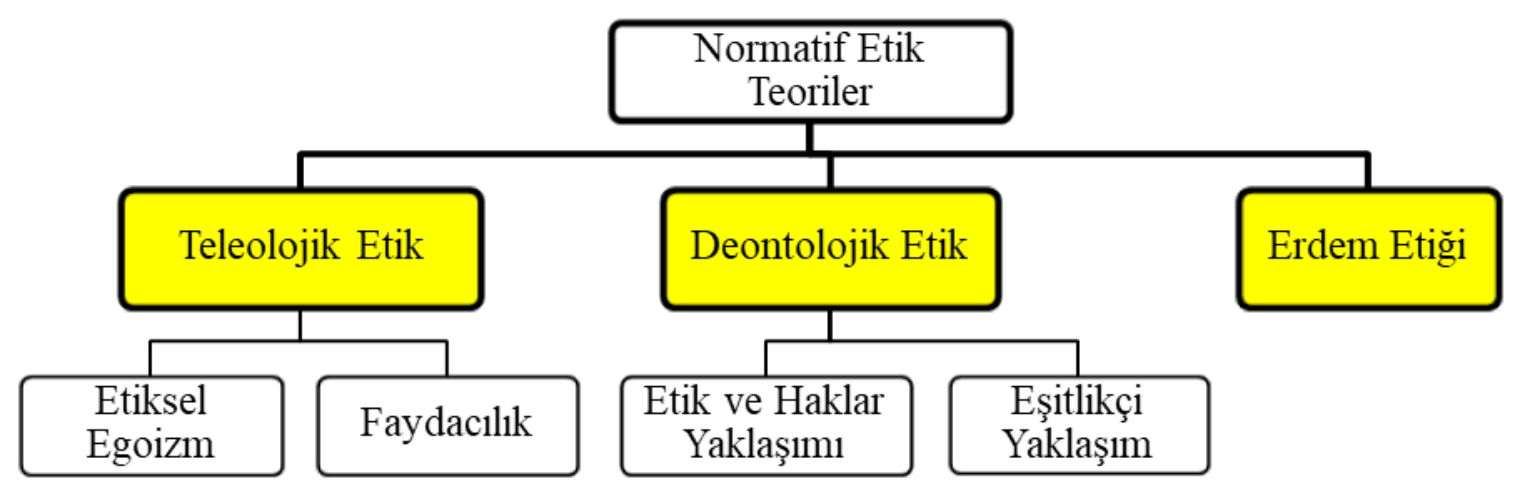

Kaynak: (Ethics Theories, 2017), (Different Kinds of Ethics, 2017)

\subsubsection{Deontolojik Etik (Kant Etiği) Yaklaşımı}

Günümüzde meslek etiğine ilişkin düzenlemeler, felsefi temelini Kant Ahlakından almaktadır. 18. yy filozoflarından olan Immanuel Kant'a göre sadece bir ahlaki görevimiz vardır: evrenselleştirilebilen ilkeler doğrultusunda davranış sergilemek. Kant, sadece evrensel kural olabilecek ilkelere (maxims) göre hareket etmemiz gerektiğini savunur. Kant'ın temsil ettiği ve ödev ahlakı olarak da adlandırılan deontolojik ahlak yaklaşımı, teleolojik etik (sonuçsalcı) anlayışının aksine, sonuçlara değil eylemin yapılma amacına dikkat eder. Diğer bir ifade ile bir eylemin ahlaki (iyi-kötü) olması, o eylemin yapılma gayesine göre belirlenmektedir. Kant'a göre, ahlaki açıdan bir yargıya varabilme için o eylemin sonucuna bakmak doğru olmaz. Kimse yapmaya niyetlendiği eylemin sonucu için garanti veremez. İyi niyetle yapılan bir eylem bazen kötü de sonuçlanabilir, fakat bu sonuç yapılan eylemin etik olmadığı anlamına gelmez (Hoffman ve Frederick, 1995: 28). Ödev ahlakına göre, eylemlerimiz "Ahlak Yasasına" uygun olmalıdır. Kant'a göre, öyle davran ki hareketlerin başkalarının hareketleri için ilke ve yasa olsun. Bu yasaya uygun hareket etmek bizim için bir ödevdir (Kant, 2010; 4:421).

Bir eylem gerçekleştirilirken göreve uymak için mi/ödevden dolayı mı, yoksa kendi çıkarımız için mi gerçekleştiriyoruz? sorusu burada yine bu eylemin ahlaki olma/olmama yargısını etkilemektedir. Kant'ın örneğine göre, bir satıcı deneyimsiz bir alıcıya fahiş fiyatla mal satmaması kesinlikle ödeve uymaktadır. Herkese sabit fiyat uygulamak bir satıcı için sağduyulu bir ticaret anlayışıdır. Bu durumda insanlar adilane bir ticaret yapmış olurlar, fakat bu tek başına satıcının, dürüstlüğün temel prensiplerine ve ahlak yasasına uyduğunu kanıtlamaz. Satıcı bunu kendi çıkarı için yapmış olabilir (örn. müşteriyi kaybetmemek) (Kant, 1998). Dolayısıyla, bir eylemi sonuçları iyi diye yapmış olmak, arka planında yapanın çıkarını besliyor ise yapılan eylem ahlaka uygun gözüküyor olsa dahi ahlaki değildir (Ünder, 2013). Her ne kadar satıcı bu davranışıyla ahlak yasasına uymuş olsa da çıkarını gözeterek bu davranışı sergilediyse ahlaki açıdan dürüst olduğu söylenemez (Bowie, 1999).

$\mathrm{Bu}$ çalışmanın yazarları, meslek hayatında da uymamız gereken kuralların Kantçı bir bakışla ödev olarak nitelendirmenin uygun olacağı görüşündedir. Örneğin, iş arkadaşlarınızla ilgili dedikodu yapmamak ahlaki açıdan bir ödev olarak nitelendirilebilir. Muhasebe mesleğinde ise, mevzuat maddelerinin birçoğu ahlaki açıdan ödev olarak nitelendirilebilir. 
Başka meslek mensuplarının ad ve unvanları kullanılarak, beyanname düzenleyememek, stajını tamamlayarak meslek ruhsatlarını aldıkları tarihten itibaren üç yıl geçmedikçe staj yaptıkları meslek mensuplarının rızası olmadan onların müşterilerine hizmet verememek, meslek mensubunun uyması gereken ödevler olarak nitelendirilebilen örneklerdendir. $\mathrm{Bu}$ açıdan, Kant Ahlakı'nın TÜRMOB disiplin yönetmeliği ile bir ilişkisi olduğu söylenebilir. Fakat bu ilişkiyi daha net ortaya koyacak başka çalışmalar yapılabilir.

\subsubsection{Teleolojik Etik Yaklaşımı}

Teleolojik etik yaklaşımında herhangi bir eylemin doğruluğu, sonuçlarının iyiliği açısından belirlenir (Reamer, 2013, s. 70). Teleolojik etik, ahlaki açıdan doğru ve yanlış olanın standardı olarak eylemin sonucunu benimseyen ve buna göre ahlaki yargıda bulunan yaklaşım olarak tanımlanabilir (Pops, 2000, s. 195). Teleolojik yaklaşımın en önemli savunucularından biri John Stuart Mill (1806-1873)'dir (Bibus III). Teleolojik yaklaşımın varsayımları kısaca; (a) en iyi sonuçları sağlayan eylem doğru eylemdir, (b) en iyi sonuç mutluluğu en yüksek seviyeye çıkaran sonuçlardır (Hursthouse, 1991).

\subsubsection{Erdem Etiği Yaklaşımı}

Erdem kavramı felsefe bilimi aşısından "İnsanın ruhsal olgunluğu” şeklinde tanımlanmaktadır (TDK Güncel Türkçe). Erdem, iyi ve anlamlı bir insan yaşamını oluşturacak karakter nitelikleri olarak tanımlanabilir. Dostça ve neşeli olmak, doğru olmak, dürüst olmak, açık ve doğru sözlü olmak, mütevazı olmak, hoşgörülü davranmak, iyi ve anlamlı bir insan hayatının bazı özelliklerindendir (Hartman \& DesJardins, 2011, s. 117).

Erdem etiği teleolojik ve deontolojik etik yaklaşımı arasında bir denge unsurudur (Banks \& Gallagher, 2009) (Bibus III). Erdem etiği eylem temelli olmaktan çok kişiyi dikkate alır, diğer bir ifade ile eyleyen temellidir. Yani bir eylem gerçekleştirilirken etik görev ve ilkelerden ya da eylemin belirli sonuçlarından ziyade eylemi gerçekleştiren kişinin erdemli ya da ahlaki karakterine bakılarak ahlaki yargıda bulunulur. Aşağıdaki tabloda etik teorilerin kısa bir karşılaştırması yapılmıştır.

Tablo 1. Normatif Etik Teorilerin Karşılaştırılması

\begin{tabular}{|c|c|c|c|}
\hline & Teleolojik Etik Yaklaşımı & Deontolojik Etik Yaklaşımı & Erdem Etiği Yaklaşımı \\
\hline Savunucusu & John Stuart Mill & Immanuel Kant & Aristoteles \\
\hline $\begin{array}{l}\text { Temel } \\
\text { Sav/Ölçüt }\end{array}$ & Eylemin Sonuçları & Eylemin Kendisi & $\begin{array}{c}\text { İnsan (Aktör - Eylemi } \\
\text { gerçekleştiren) }\end{array}$ \\
\hline İyi nedir? & $\begin{array}{c}\text { Bir eylemin sonucunda } \\
\text { maksimum fayda elde ediliyorsa, } \\
\text { iyidir. }\end{array}$ & $\begin{array}{l}\text { İyi, doğru eylemin ta kendisidir. } \\
\text { Eylemi gerçekleştirme } \\
\text { nedeni/amacı doğru ise ve ödeve } \\
\text { uyuyor ise iyidir. }\end{array}$ & $\begin{array}{l}\text { Erdemli insanların eylemleri, } \\
\text { sonucu her ne olursa olsun } \\
\text { iyidir. Erdemli bir insanın bir } \\
\text { olay karşısında sergileyeceği } \\
\text { davranıştır. }\end{array}$ \\
\hline Doğru nedir? & $\begin{array}{l}\text { “'̇yi’yi maksimuma çıkaran } \\
\text { eylemlerdir. En iyi sonuçları } \\
\text { veren eylem doğru eylemdir. }\end{array}$ & $\begin{array}{l}\text { Bir eylem, ahlaki bir kural ya da } \\
\text { ilkeye uygun olduğu sürece } \\
\text { doğrudur. }\end{array}$ & $\begin{array}{c}\text { Bir eylemin doğruluğunu } \\
\text { erdemli bir kişinin ilgili } \\
\text { eyleme karşı yapacağı hareketi } \\
\text { gösterir. }\end{array}$ \\
\hline Sorusu nedir? & $\begin{array}{l}\text { Eylemim sonucunda ne tür } \\
\text { sonuçlar üretmeliyim, } \\
\text { maksimum faydayı sağlayacak } \\
\text { sonuç nedir? }\end{array}$ & $\begin{array}{c}\text { Bir eylem karşısında benim } \\
\text { sorumluluklarım/ödevim nelerdir } \\
\text { ve asla yapmamam gereken } \\
\text { şeyler nelerdir? }\end{array}$ & $\begin{array}{l}\text { Nasıl bir kişi olmalıyım, } \\
\text { hareketlerim karakterimi nasıl } \\
\text { gösterecek? }\end{array}$ \\
\hline
\end{tabular}

Kaynak: (Whetstone, 2001) ve (Hursthouse, 1991) uyarlanmıştır. 
Tablo 1'de görüldüğü üzere erdem etiğini diğer etik yaklaşımlardan ayıran temel nitelik ahlaki yargıda bulunma ölçütleridir. Erdem etiği, eylemin sonucu (teleolojik yaklaşım) ya da yapılış gayesinden (deontolojik yaklaşım) ziyade bireyin davranışları bağlamında olaya yaklaşmaktadır.

Hursthouse (1996, s. 22) çalışmasında "faydacılık (teleoloji) iyi üzerinden/açısından doğruyu tanımlıyor, deontoloji doğru üzerinden/açısından iyiyi tanımlıyor, peki erdem etiği erdemli insan üzerinden/açısından her ikisini (iyi-doğru) nasıl açıklayabilir?" şeklinde bir soru sorarak bir anlamda bu üç varsayım arasındaki temel farklılığı da ortaya koymaktadır. Hursthouse (1996) doğru bir eylemi, erdemli bir kişi tarafından belirli koşullar altında karakteristik olarak yapılan bir eylem olarak tanımlamaktadır.

\subsection{Etik İkilemler}

Aristoteles'in erdem, Kantın ödev ve Mill'nin en yüksek mutluluk ilkesi bir etiksel ikilem ile karşı karşıya kalındığında yapılması gereken doğru şeyin ne olduğu sorusuna farklı ahlaki ölçütler ile cevap veren ahlaki yaklaşımlardır (Belak \& Rozman, 2012, s. 1607).

Svara'nın şematize etmiş olduğu "Etik Üçgeni” etik ikilemler için üç yaklaşımı temsil etmektedir: sonuç, ilke ve erdem. Sonuçlar yaklaşımını (teleoloji) kullanarak bir ikilimi ele alırken, karar verici en yüksek faydayı sağlayacak sonuçları değerlendirmelidir. Kurallar/İlkeler yaklaşımı, karar vericiye kararın adil, dürüst veya eşit olup olmadığını incelemesini sağlar. Erdem yaklaşımı ise verilen kararın erdemli bir insanın karakteristiği ile uyuşup uyuşmadığını sorgulama firsatı sunar (West \& Berman, 2006, s. 30-31).

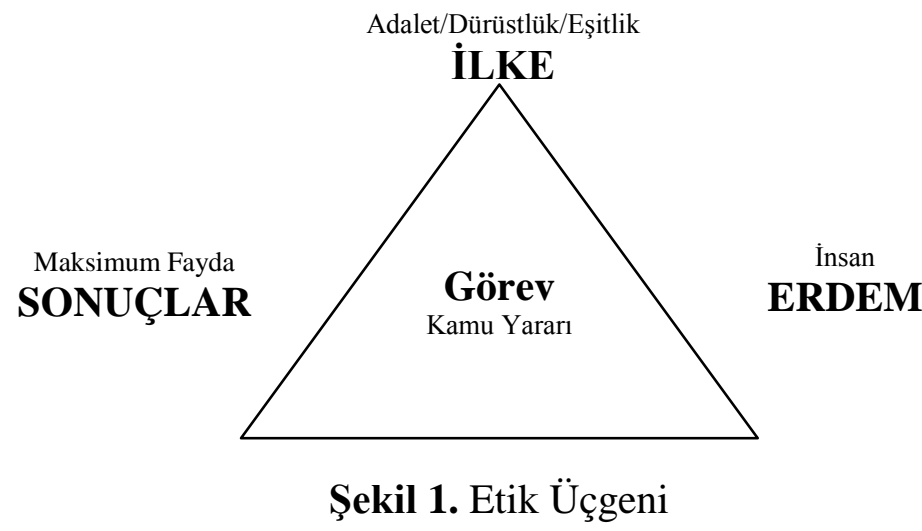

Kaynak: (Svara, 2007, s. 68)

Bir karar alınacağında etik kaygısı oluşturacak ikileme düşülür ise eylemi gerçekleştirecek kişi bu durumdan bir çıkış noktası arayacaktır. Yani alacağı kararın etik olduğuna kendisini inandıracak argümanlar bulmalıdır. Yapmış olduğu faaliyeti etik bir zemine oturtmak için çoğu kez etik üçgeninde bulunan etik yaklaşımların varsayımları doğrultusunda hareket edecektir. Bir diğer ifadeyle, yapacağı işin aslında kararını vermiş olsa dahi vicdani olarak etik zemine oturtmak isteyecektir. Böyle durumlarda çoğu kişi farklı yaklaşımların varsayımlarını benimseyecektir. Örneğin, bir hasta ziyaretinde durumu ağır olan hastaya, moral vermek için söylenen "çok iyi görünüyorsun" yalanı aslında normal 
şartlarda yalan söylemenin etik olmamasına rağmen ilgili durumda kişilerin bu davranışı etik olarak değerlendirmesine sebep olmaktadır. Bu eylem Etik Üçgeni bağlamında düşünüldüğünde iyi bir amaca yönelik yapıldığı için deontolojik (görev/ilke) yaklaşım varsayımı altında etik olarak görülmektedir ve ikilemden çıkış noktası deontolojik etik varsayımıdır. Öte yandan her ne koşulda olursa olsun yalan söylemek erdemli bir insanın davranışı olmayacaktır.

Etik ikilemlerin çözümünde eylemi gerçekleştiren aktörün ve eylemin kendisinin hangi etik yaklaşım bağlamında çözüme kavuşturulduğunun tartı̧̧ılması, aktörün yapmış olduğu eylemi etik olarak değerlendirdiği varsayımı altında yapılabilir. Aksi takdirde (yani kişi yaptı̆̆ının etik olmadığını bilerek yapıyor ise) etik ikilemin oluşmadığı ve etik yaklaşımlar açısında konuyu ele almanın anlamlı olmayacağı söylenebilir. Çünkü yapılan eylemin etik kaygısı taşımadan yapılıyor olması, aktörü ikileme sokmayacağı gibi bunun sonucunda da bir çıkış noktası arama gereksinimi de doğurmayacaktır.

\section{MUHASEBE MESLEĞINDE MESLEK AHLAKINA İLişKIN YASAL DÜZENLEMELER}

Kant, Platon ve Durkheim'in belirtilen görüşleri dikkate alındığında ahlaka uygunluk konusu meslek mensupları açısından bir takım yasal düzenlemeler yoluyla hayat bulmaktadır. Birçok meslekte olduğu gibi muhasebe mesleğinde de birçok konu, kanun ve yönetmeliklerle düzenlenmiştir. Bununla birlikte, meslek mensuplarının içinde bulunmuş oldukları bazı durumlar her zaman bu mevzuatta yer almayabilir. Diğer bir ifadeyle, her durum ya da her olay için önceden tanımlanmış bir kural ya da ilke olmayabilir ya da yapılan kötü niyetli girişim başkaları tarafından fark edilmeyebilir. Hatta, Kantçı yaklaşıma göre, ahlaka uygun görünüp ahlaki olmayan bir davranış da sergilenmiş olabilir. Bu gibi durumlarda meslek mensubunun davranışı değer yargılarına ve ahlaki duruşuna göre değişebilmektedir. Çalışmanın giriş bölümünde de değinilen etik ikilemlere düşme konusu muhasebe meslek mensuplarının zaman zaman karşılaştığı bir durumdur. Bu durumlarda doğru kararı vermek her zaman çok kolay olmamaktadır.

Mesleği düzenleyici kurumlar meslek mensuplarını bu ikilemlerden kurtarmak ve mesleğin itibarını korumak için meslek mensuplarının uymaları gereken mevzuat yayınlamışlardır. Muhasebe mesleğinde meslek ahlakına ilişkin olarak aşağıdaki yasal düzenlemeler mevcuttur.

Serbest Muhasebeci Mali Müşavirler ve Yeminli Mali Müşavirlerin Mesleki Faaliyetlerinde Uyacakları Etik İlkeler Hakkında Yönetmelik,

$>$ Serbest Muhasebecilik, Serbest Muhasebeci Mali Müşavirlik ve Yeminli Mali Müşavirlik Meslek Ahlak Kuralları ile İlgili Mecburi Meslek Kararı

\section{BİR MUHASEBE MESLEK ODASI TARAFINDAN VERILMIŞ DİSIPLIN CEZALARININ ANALIZI}

Çalışmanın bu bölümünde araştırmanın yöntemi ve disiplin cezası gerektiren fiillerin analizi verilmeye çalş̧ılacaktır. Araştırmanın yöntemi belirtilirken araştırma konusunun da ortaya çıkış süreci ve veri toplama aşamaları anlatılmaktadır. Disiplin cezalarını gerektiren 
fiillerin analizi kısmında ise bir SMMM odasından alınan 2008-2013 dönemine ilişkin disiplin cezaları ve bu cezaların verilmesine neden olan eylemler verilmiştir.

\subsection{Araştırmanın Yöntemi}

$\mathrm{Bu}$ araştırmada yöntem olarak nitel araştırma yöntemi benimsenmiştir. Çalışmanın konusu dikkate alındığında nitel araştırma yöntemi ile derinlemesine araştırılması uygun olacaktır. Çünkü anket yönteminde katılımcılar ahlakla ilgili sorulara objektif cevap veremeyecekleri pilot çalışma ile ortaya çıkmıştır. Bir gruba (SMMM), meslek mensuplarının etik algısını ölçmek amaçlı anket soruları verilmiştir. Katılımcılar, sunulan anketteki sorulara objektif yanıt veremeyeceklerini beyan etmişlerdir.

$\mathrm{Bu}$ pilot anket çalışması sonucunda insanların etik ile ilgili yapılan anket sorularına genelde olanı değil, olması gerektiği şekilde cevap verildiği kanısına varılmıştır. Diğer bir ifade ile etik olmayan davranışta bulunulsa dahi, kişinin etik olmayan davranışı sergileyeceğini beyan etmeyeceği sonucu ortaya çıkmaktadır. Bu durum Kant etiği ve Platon'un Gyges örneği ile ilgili verilen literatüre bir paralellik arz eder. Bu durumda etkonusu hakkında yanıltıcı olmayan bilgilere ulaşarak daha sağlıklı sonuçlara ulaşabilmek için meslek odasının vermiş olduğu cezaların incelenmesinin doğru olacağına karar verilmiştir. Bu durum aynı zamanda böylesi bir konunun metodolojik olarak hangi sınırlılıklar içerisinde çalışılabileceğine dair de bir yol sunmaktadır.

$\mathrm{Bu}$ bağlamda, bir meslek odasından alınan izinle 2008-2013 döneminde verilen disiplin cezalarının hangi eylemlerden kaynaklandığı ahlak felsefesi açısından incelenmeye çalışılmıştır. Araştırmanın yöntemi olarak meslek odasının izniyle ulaşılan disiplin cezalarının tümü, meslek mensubunun ismi gizli tutularak detayları ile incelenmiştir. Bu inceleme sonucunda disiplin cezaları tasnif edilerek, hangi yıl, hangi tip disiplin cezalarının verildiği sınıflandırılmıştır. Ancak, bu araştırma sonucunda elde edilen veriler kişi ya da kurumların haklarını koruma kaygısı sebebiyle incelenen disiplin cezaları tüm detayları ile verilemeyecek olup, sadece kısa açıklamalar şeklinde sunulacaktır. Ayrıca bu durum araştırmamızın birinci kısıtını oluşturmaktadır. Zira bilimsel etik gereği disiplin cezaları alan meslek mensupları ve vakalar ifşa edilemez. Öte yandan, bir diğer kısıt ise ilgili meslek odasının inceleme yılını 2008 ve 2013 arası olarak sınırlamasıdır. Meslek odasının daha geriye yönelik veri incelemesi konusunda istekli olmaması nedeniyle sadece belirtilen yıllar arasında verilen cezalar incelenebilmiştir.

\subsection{Disiplin Cezalarını Gerektiren Fiillerin Analizi}

2008-2013 döneminde toplam 64 vakaya rastlanmıştır. Bu 64 vakanın, 15'i 2012 y1lına, 6's1 2011 yılına, 3'ü 2010 yılına, 35'ü 2009 ve 5 vaka ise 2008 y1lına aittir. 2013 yılında ise herhangi bir disiplin cezası mevcut değildir. Ayrıca incelenen cezalar disiplin yönetmeliğinde belirtilen ceza sınıflandırılmasına göre kategorize edilmiştir. Buna göre cezalar ve bu cezaların verilme sayıları; Uyarma (44), Kınama (15), Geçici Olarak Meslekten Alıkoyma (4) ve son olarak Meslekten Çıkarma (1) şeklindedir. Aşağıda cezaların yıllara göre oranlarını gösteren grafik bulunmaktadır: 


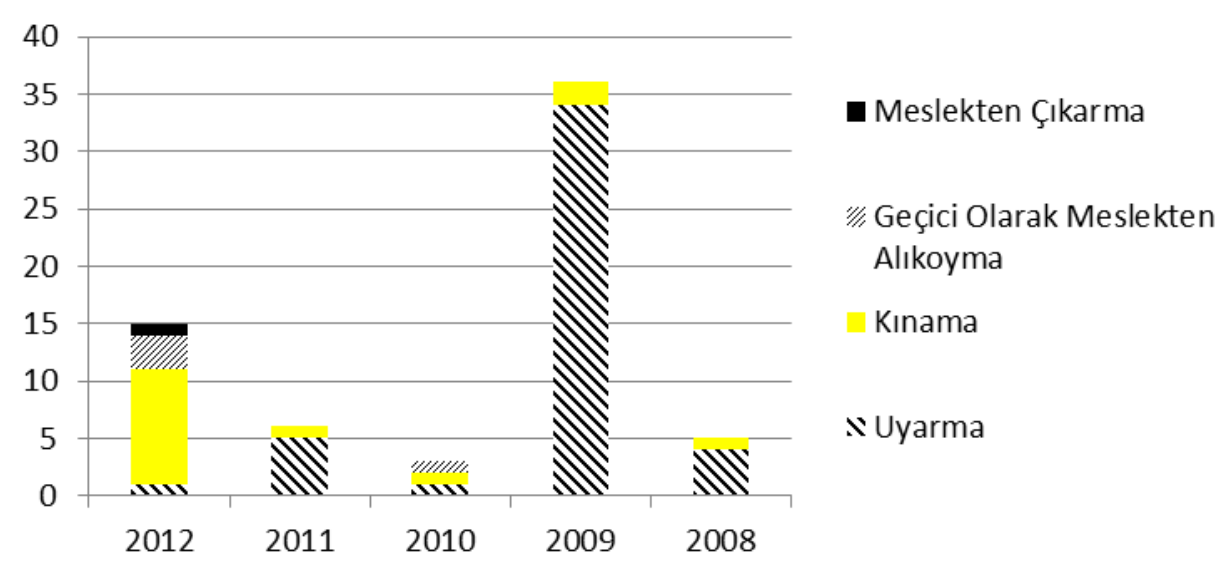

Grafik 1: Disiplin cezalarının türlerine göre yıllar itibariyle dağılımı

Aidat borçları sebebiyle alınan uyarı cezaları (31) haricinde kalan cezaların tamamı, odaya gelen şikâyet dilekçesi gereği yapılan inceleme sonucu verilen cezalardan oluşmaktadır. $\mathrm{Bu}$ şikâyetler bazen meslek mensubunun meslektaşını, müşterinin meslek mensubunu, Gelir İdaresi Başkanlığının ve Vergi Dairelerinin dilekçeleri üzerine yapılan soruşturmalardan oluşmaktadır. İncelemeler verilen cezalar üzerinden gerçekleştirilmiş olup, bazı vakalarda birden fazla suç aynı anda işlenmiş olmasına rağmen rakamsal olarak sadece bir kez gösterilebilmiştir.

Alınan cezaları gerektiren eylemlerin bazılarını incelediğimizde; bir vakada meslek mensubu defterini tuttuğu mükellefin bilgisi olmadan belli bir sayıda kişiyi işletmeye çalışan olarak gösterip Sosyal Güvenlik Kurumu (SGK) girişlerini gerçekleştirmiştir. Bu olay sonucunda disiplin yönetmeliğinin 5 . maddesinin (a) ve (m) bendi gereği müşterilerle mesleki konularda yapılacak sözleşme hükümlerine aykırı davranılması ve mesleğin vakar ve onuruna aykırı davranışlarla, görevin gerektirdiği güveni sarsıcı hareketlerde bulunulması sebebiyle kınama cezası verilmesine hükmedilmiştir.

Bir diğer vakada ise yanında stajını tamamladığı meslek mensubunun mükellefinin defterini iki yıl dolmadan kendi adına açtığ 1 büroda tutmak eylemi nedeni ile disiplin yönetmeliğinin 6(ş) maddesi gereğince kınama cezası ile cezalandırılmış. Takip eden yıl aynı eylemler tekrarlanmış ve aynı yönetmeliğin 7(a) ve 7(e) maddeleri gereğince üç yıllık bir dönem içinde kınama cezası gerektiren eylemin yinelenmesi ve ticari faaliyet yasağına uyulmaması sebebiyle 9 ay geçici olarak meslekten alıkoyma cezası ile cezalandırılmıştır.

Birden fazla ceza gerektiren eylemde bulunulan bir vaka da ise meslek mensubu mükellefinin ilgili ay vergi matrahını fazla göstermesi ve buna istinaden mükelleften fazla para alması ve aldığı bu para için de sahte dekont düzenlemesi kovuşturma konusudur. Yapılan bu eylemleri de yanında çalışan bir personelin yaptığını iddia etmiştir. Bu eylem üzerine disiplin yönetmeliğinin 7(d) ve 7(f) maddesi gereği 9 ay geçici olarak meslekten alıkoyma cezası ile cezalandırılmıştır. Aynı vaka ile ilgili sahte belge düzenleme eylemi 3 . kez tekrarlanarak daha sonra aynı şahıs disiplin yönetmeliğinin 9(a) maddesi gereği meslekten çıkarma cezası ile cezalandırılmıştır. Bu vakada meslek mensubu ilk olarak, müşterisine ait para veya diğer varlıkları, emanet olarak alamayacağı etik ilkesine ters düşmüştür. Bu eylem 
etik ilkelere uymamasına rağmen, mevzuatta eylemle ilgili tanımlanan bir ceza mevcut değildir. Haksız yere (vergi matrahını fazla göstererek) fazla para alınması ile cezayı gerektirecek eylem gerçekleştirilmiştir. Alınan fazla parayı meşru göstermek için düzenlenen dekont sahte belge düzenlemeye girmesi sebebiyle bir diğer cezayı gerektiren eylem olmakla birlikte kovuşturmayı yapan oda bu sebepten ötürü meslek mensubu hakkında Cumhuriyet Savcılığı'na suç duyurusunda bulunulması kararı almıştır. Meslek mensubunun yapmış olduğu bu fiilleri yanında çalışan kişiye isnat etmesi, meslek mensubunun olayla ilgili sorumluluğunu kaldırmaz. Çünkü meslek mensubu yanında çalıştırdıkları kişilerin mesleki faaliyet ile ilgili eylemlerinden de mesuldür.

Tablo 2 ceza gerektiren eylemler ve verilen cezalar yıllar itibari ile kısaca vermektedir. İlgili tabloda her eylemin altında yer alan "Eylem Sayısı" belirtilen eylemin ilgili yıl içinde gerçekleşme sayısını göstermektedir. 3 vaka da disiplin cezasını gerektiren fiil, disiplin karar defterinde verilmemiş olup direkt dosya erişiminin SMMM odası tarafindan kısıtlanması nedeniyle verilememiştir. İlgili cezaların sadece hangi maddeden ve ne şekilde (GIB, SGK yazısı ile) tespit edildiği belirtilebilmiştir.

\subsection{Aktörün Eyleminin Gerekçelendirilmesinin "Etik İkilemden Çıkış" Kavramı Açısından Değerlendirilmesi}

Tablo 3'de disiplin cezaların gerektiren eylemler, eylemin amacı ve eylemin sonucunda fayda gören/zarara uğratılan gruplar açısından değerlendirilerek, yapılan bu eylemlerin bu değerlendirme çerçevesinde normatif etik teoriler (teleolojik etik yaklaşımı, deontolojik etik yaklaşımı ve erdem etiği yaklaşımı) bakış açısıyla hangi teoriye aykırı olduğu belirlenmeye çalışılmıştır.

Etik ikilemler başlı̆ı altında da bahsedildiği gibi incelenen eylemlerin, eylemin aktörü tarafından etik olmadığı bilinmesine rağmen gerçekleştiriliyor olması, kişinin etik davranma kaygısı taşımadığını gösterir. Bu sebeple, bu tür eylemler çalışmada belirtilen etik ikilemlerden çıkış argümanları kapsamı dışında kalmaktadır. İncelenen eylemler etik kaygısı taşıyarak ve etik ikileme düşüldükten sonra gerçekleştiriliyor olduğu varsayımıyla ele alınmıştır. $\mathrm{Bu}$ varsayım doğrultusunda incelenen eylemlerin aktörün aslında teleolojik etik yaklaşımı doğrultusunda hareket ederek eylemi gerçekleştirdiği söylenebilir. Gerçekleştirilen eylemlerin teleolojik etik yaklaşımının Etiksel egoizm (kendine çıkar sağlamak) ve faydacılık varsayımlarının bir tezahürü olarak ortaya çıktığı söylenebilir. Çünkü her bir faaliyet sonucunda bir çıkar grubuna fayda sağlamak amaç edinilmiştir. Her bir eylemin sonucunda meslek mensubu kendisine, müşterisine ya da üçüncü şahıslara fayda sağlamak amaçlı bu eylemleri gerçekleştirdiği görülmektedir. 
Tablo 2. Y1llar İtibari İle Ceza Gerektiren Eylemler ve Verilen Cezalar

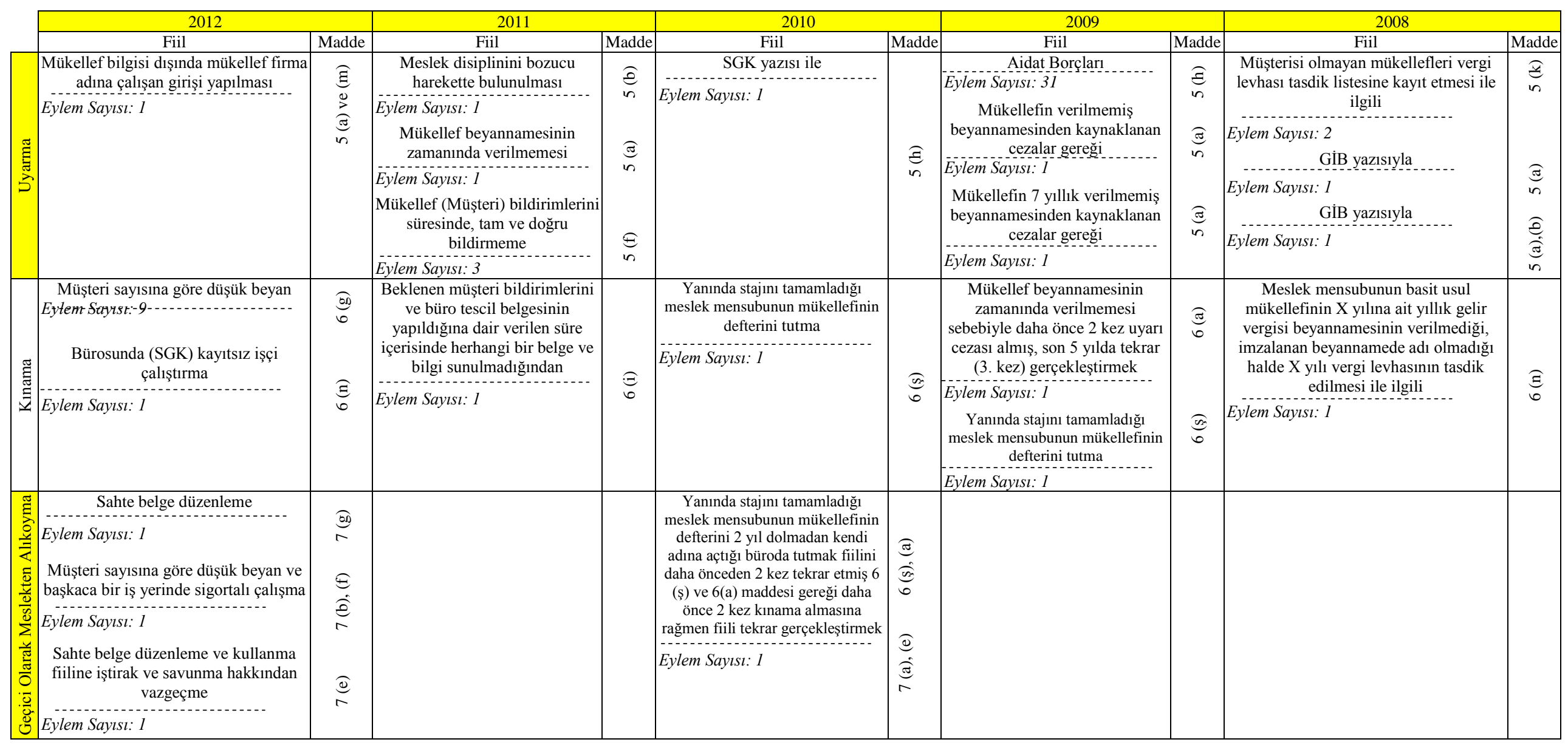




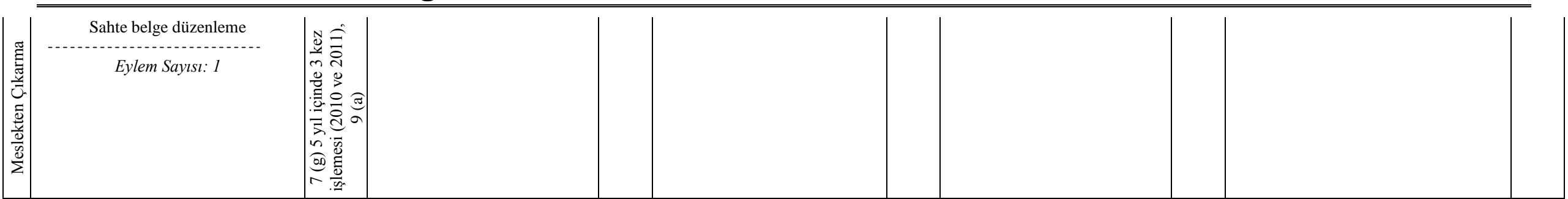

Tablo 3. Disiplin Cezalarına Konu Eylemin Etik Yaklaşımlar Açısından İncelenmesi

\begin{tabular}{|c|c|c|c|c|c|}
\hline Disiplin Cezasına Konu Eylem & Eylemin Amac1 & Çıkar Grubu & Zarara Uğratılan & & Aykırı Olduğu Etik Anlayışı ve Gerekçesi \\
\hline \multirow{2}{*}{$\begin{array}{l}\text { Yanında stajını tamamladığı meslek } \\
\text { mensubunun mükellefinin defterini } \\
\text { tutma }\end{array}$} & \multirow[t]{2}{*}{ Kazanç sağlamak } & \multirow{2}{*}{$\begin{array}{l}\text { Meslek } \\
\text { mensubunun } \\
\text { kendisi }\end{array}$} & \multirow{2}{*}{$\begin{array}{l}\text { Yanında stajını } \\
\text { tamamladığ } 1 \\
\text { meslek mensubu }\end{array}$} & Deontoloji & $\begin{array}{l}\text { Eylemin amacının kazanç sağlamak olması ilk bakışta deontolojik } \\
\text { etik yaklaşımı açısında bir sorun teşkil etmiyor gibi görünse de } \\
\text { kazancın uygun olmayan bir yoldan sağlanıyor olması ve eylemin } \\
\text { özünde iyi niyetli bir amaç taşımadığı açıktır. Bu sebeple bu eylem } \\
\text { deontolojik etik yaklaşımına aykırı olarak değerlendirilebilir. }\end{array}$ \\
\hline & & & & Erdem Etiği & $\begin{array}{l}\text { Yapılan eylem bir vefasızlıktır. "Vefasızlık" sıfatı erdemli bir } \\
\text { kişide olmaması gereken bir sıfattır. Bu sebeple bu eylem Erdem } \\
\text { etiği yaklaşımına göre de etik değildir. }\end{array}$ \\
\hline \multirow[t]{2}{*}{$\begin{array}{l}\text { Mükellef bilgisi dışında mükellef firma } \\
\text { adına çalışan girişi yapılması }\end{array}$} & \multirow[t]{2}{*}{$\begin{array}{l}\text { 3. şahıslara fayda } \\
\text { sağlamak }\end{array}$} & \multirow[t]{2}{*}{$\begin{array}{l}\text { 3. şahıslar ve } \\
\text { kendisi }\end{array}$} & \multirow[t]{2}{*}{ Devlet ve Müşteri } & Deontoloji & $\begin{array}{l}\text { 3. kişilere fayda sağlamak ve ödev olarak nitelendirebileceğimiz } \\
\text { kanunlara aykırı davranışta bulunuluyor olması eylemin } \\
\text { deontolojik etik yaklaşımı açısından etik olmadığını } \\
\text { göstermektedir. Bu eylemde iki farklı boyut söz konusudur. } \\
\text { Bunlardan ilki eylemi gerçekleştirenin, müşterisinin izni ve bilgisi } \\
\text { dışında müşteri firması adına çalışan girişi yapılması durumudur. } \\
\text { İkincisi ise çalışan olarak girişi yapılan işçiye ait sigorta } \\
\text { primlerinin işverene ödettirilmesidir. İki durumda da gayri ahlaki } \\
\text { bir eylem söz konusudur, lakin eylemin şiddeti ikincide daha } \\
\text { yüksektir. }\end{array}$ \\
\hline & & & & Erdem Etiği & $\begin{array}{l}\text { Meslek mensubunun müşterisinin kendisine güvenerek vermiş̧, } \\
\text { olduğu yetkileri kötüye kullanarak, müşterisine bir nevi "ihanet" } \\
\text { etmiş olmaktadır. Bu da yine erdem etiği yaklaşımına aykırı bir } \\
\text { harekettir. }\end{array}$ \\
\hline $\begin{array}{l}\text { Meslek disiplinini bozucu harekette } \\
\text { bulunulması (haksız rekabet vb.) }\end{array}$ & Kazanç sağlamak & $\begin{array}{l}\text { Meslek } \\
\text { mensubunun } \\
\text { kendisi }\end{array}$ & Mesleğin kendisi & Deontoloji & $\begin{array}{l}\text { Meslek mensubunun mesleğin belirlemiş olduğu kurallara aykırı } \\
\text { davranarak meslek vakar ve onurunu düşürücü hareketlerde } \\
\text { bulunması deontolojik etik yaklaşımı aşısından ödeve uyulmadığ1 }\end{array}$ \\
\hline
\end{tabular}




\begin{tabular}{|c|c|c|c|c|c|}
\hline Disiplin Cezasına Konu Eylem & Eylemin Amacı & Çıkar Grubu & Zarara Uğratılan & & Aykırı Olduğu Etik Anlayışı ve Gerekçesi \\
\hline & & & & & için etik dışı davranış olarak nitelendirilebilir. \\
\hline \multirow{2}{*}{$\begin{array}{l}\text { - Mükellef beyannamesinin zamanında } \\
\text { verilmemesi } \\
\text { - Mükellef (Müşteri) bildirimlerini } \\
\text { süresinde, tam ve doğru bildirmeme } \\
\text { - Mükellefin verilmemiş } \\
\text { beyannamesinden kaynaklanan } \\
\text { cezalar gereği }\end{array}$} & \multirow[t]{2}{*}{-} & \multirow[t]{2}{*}{-} & \multirow{2}{*}{$\begin{array}{l}\text { Müşteri ve } \\
\text { Meslek }\end{array}$} & Deontoloji & $\begin{array}{l}\text { Bu eylemde meslek mensubu görevini yerine getirmemiştir. } \\
\text { Mesleğin ve müşterinin kendisinden haklı olarak beklemiş olduğu } \\
\text { ve aynı zamanda meslek mensubunun da görevi olan işleri } \\
\text { zamanında, tam ve doğru olarak yerine getirmemesi ödev olarak } \\
\text { nitelendirebileceğimiz görevlerini aksattığını göstermektedir. Bu } \\
\text { sebeple deontolojik etik yaklaşımına göre etik olmayan davranış } \\
\text { sergilemiş olduğu söylenebilir. }\end{array}$ \\
\hline & & & & Erdem Etiği & $\begin{array}{l}\text { Mesleğin ve müşterinin haklı olarak beklediği faaliyetleri } \\
\text { zamanında yerine getir(e)memiş olması meslek mensubuna olan } \\
\text { güveni zedeleyici bir durumdur. Erdemli bir kişi aynı zamanda } \\
\text { güvenilir olma vasfinı da taşıması gerekir. Burada yaratılan } \\
\text { "güvensizlik" erdem etiği açısından erdemli kişi karakteristiğine } \\
\text { uymamaktadır. }\end{array}$ \\
\hline $\begin{array}{l}\text { Müşterisi olmayan mükelleflerin vergi } \\
\text { levhasını tasdik etmesi }\end{array}$ & Kazanç Sağlamak & & $\begin{array}{l}\text { Devlet ve } \\
\text { Mesleğin kendisi }\end{array}$ & Deontoloji & $\begin{array}{l}\text { Deontolojik etik yaklaşımında görev/ödev olarak nitelendirilen } \\
\text { kanuna ve zorunlu meslek kurallarına aykırı davranışta bulunmak } \\
\text { etik olmayan davranışlardan sayılabilir. }\end{array}$ \\
\hline \multirow[b]{2}{*}{ Müşteri sayısına göre düşük beyan } & \multirow[b]{2}{*}{ Vergi Kaçırma } & \multirow{2}{*}{$\begin{array}{l}\text { Meslek } \\
\text { mensubunun } \\
\text { kendisi }\end{array}$} & \multirow[b]{2}{*}{ Devlet } & Deontoloji & $\begin{array}{l}\text { Kanunlara aykırı faaliyette bulunma deontolojik etik yaklaşımına } \\
\text { aykırı bir eylemdir, çünkü kanunlar, uymamız gereken ödevler } \\
\text { olarak nitelendirilebilir. Vergi ödemek yerine getirilmesi gereken } \\
\text { görevlerimizdendir. }\end{array}$ \\
\hline & & & & Erdem Etiği & $\begin{array}{l}\text { Burada meslek mensubu müşteri sayısını eksik göstererek vergi } \\
\text { kaçırma eylemini gerçekleştirmiştir. Vergi ödemenin kanuni bir } \\
\text { zorunluluk olmasının yanında bir vatandaşlı görevi olduğu da } \\
\text { düşünüldüğ̈ünde vergi kaçımanın erdemli bir kişinin } \\
\text { karakteristiğine uymamaktadır. }\end{array}$ \\
\hline \multirow[t]{2}{*}{$\begin{array}{l}\text { Bürosunda (SGK) kayıtsız işçi } \\
\text { çalıştırma }\end{array}$} & \multirow[t]{2}{*}{ Kazanç sağlamak } & \multirow{2}{*}{$\begin{array}{l}\text { Meslek } \\
\text { mensubunun } \\
\text { kendisi }\end{array}$} & \multirow[t]{2}{*}{ Devlet ve Çalışan } & Deontoloji & $\begin{array}{l}\text { Burada daha az maliyete katlanmak için işçinin hakkına ve devletin } \\
\text { koyduğu kanunlara aykırı davranılması deontolojik etik yaklaşımı } \\
\text { bakış açısıyla etik olmayan bir davranış olarak nitelendirilebilir. }\end{array}$ \\
\hline & & & & Erdem Etiği & $\begin{array}{l}\text { Burada çalışana karşı yapılan "haksızlık” erdem etiğine aykırı } \\
\text { düşmektedir. Erdemli bir insan çalışanının hakkını korur. }\end{array}$ \\
\hline Başka bir iş yerinde sigortalı çalışma & Kazanç sağlamak & $\begin{array}{l}\text { Meslek } \\
\text { mensubunun }\end{array}$ & Mesleğin kendisi & Deontoloji & $\begin{array}{l}\text { Deontolojik etik yaklaşımında görev/ödev olarak nitelendirilen } \\
\text { kanuna ve zorunlu meslek kurallarına aykırı davranışta bulunmak }\end{array}$ \\
\hline
\end{tabular}




\begin{tabular}{|c|c|c|c|c|c|}
\hline Disiplin Cezasına Konu Eylem & Eylemin Amacı & Çıkar Grubu & Zarara Uğratılan & & Aykırı Olduğu Etik Anlayışı ve Gerekçesi \\
\hline & & kendisi & & & etik olmayan davranışlardan sayılabilir. \\
\hline & & & & Erdem Etiği & $\begin{array}{l}\text { Başka bir iş yerinde sigortalı çalışarak meslek kurallarını ihlal eden } \\
\text { meslek mensubunun erdem etiğine de aykırı davrandığ } 1 \\
\text { söylenebilir. Mensubu olduğu mesleğin kurallarına aykırı } \\
\text { davranarak mesleğin vakar ve onurunu düşürücü faaliyette } \\
\text { bulunulmuş olmaktadır. }\end{array}$ \\
\hline \multirow{2}{*}{$\begin{array}{l}\text { Sahte belge düzenleme ve kullanma } \\
\text { fiiline iştirak }\end{array}$} & \multirow{2}{*}{$\begin{array}{l}\text { Müşteriye ve } \\
\text { kendisine fayda } \\
\text { sağlamak }\end{array}$} & \multirow{2}{*}{$\begin{array}{l}\text { Müşteri ve } \\
\text { Meslek } \\
\text { mensubu }\end{array}$} & \multirow{2}{*}{$\begin{array}{l}\text { Devlet ve } \\
\text { Mesleğin kendisi }\end{array}$} & Deontoloji & $\begin{array}{l}\text { Devletin koymuş olduğu kurallara aykırı davranılıyor olması } \\
\text { deontolojik etik yaklaşımına göre ödeve uymamak olarak } \\
\text { nitelendirilmektedir ve etik olmayan davranışlar kapsamına } \\
\text { girmektedir. }\end{array}$ \\
\hline & & & & Erdem Etiği & $\begin{array}{l}\text { Burada yapılan eylem yetkili kurumları gerçek dişı belgelerle } \\
\text { yanıltıcı işlemlerde bulunmaktır. Bu da erdemli bir kişinin } \\
\text { yapmayacağı işlerle örtüşmemektedir. Bu sebeple bu eylem Erdem } \\
\text { etiği yaklaşımına göre de etik değildir. }\end{array}$ \\
\hline
\end{tabular}




\section{SONUÇ}

Çalışmada incelenen dönem kapsamında 64 adet disiplin cezasına konu eylem incelenmiştir. $\mathrm{Bu}$ eylemlerin 31 tanesi oda aidatının ödenmemesi sonucunda verilen uyarı cezalarından oluşmaktadır. İlgili dönemde "Meslekten Men" (1), "Geçici Olarak Meslekten Alıkoyma" (4), "Kınama" (15) ve (oda aidatlarının ödenmemesi dışında kalan) uyarı cezasını (13) gerektiren eylem(ler) rapor edilmiştir. Oda aidatlarının ödenmemesi dışındaki eylemler arasında cezaların yoğunlaştığı eylemler mükellef beyanname ve bildirimlerinin zamanında ve tam olarak verilmemesi sonucunda mesleğin gereğini yerine getirmeme eyleminden kaynaklanan cezalardan oluşmaktadır.

$\mathrm{Bu}$ çalışma sonucunda muhasebe meslek mensuplarına verilen disiplin cezaları göstermektedir ki bazı meslek mensubu bir ya da birkaç kez etik olmayan davranış sergilemiştir. Ayrıca meslek örgütünün mevcut mevzuatının olmaması durumunda bu türden davranışlar kişinin değer yargılarına göre artacaktır. Dolayısıyla bu konuda düzenleyici mevzuatın var olması etik ihlallerini azaltıcı bir etkiye sahip olduğu söylenebilir. Disiplin cezası alan meslek mensupları Resmi Gazete yoluyla kamuya duyurulmaktadır. Fakat bu duyuruda cezaya neden olan eylem açıklanmamaktadır. Bu eylemin açıklanması etik dışı davranışların azalması sonucunu doğuracaktır.

Ayrıca etik dışı eylemlerin ortaya çıkarılmasının ve takibe konu edilmesinin tek yolunun şikayet müessesidir. Buradan hareketle şikayet edilmeyen daha pek çok etik dişı eylemler olabileceği sonucuna ulaşılabilir. Görünürde disiplin mevzuatının temelinde yatan amacın mesleğin itibarını ve meslek mensubunu kendisini korumak ve meslektaşlar arası ilişkiyi düzenlemeye yöneliktir. Bu yönüyle deontolojik olduğu söylenebilir. Fakat bu amaç nihayetinde kamu yararı ve meslek mensuplarının müşterilerini korumaya hizmet etmektedir. $\mathrm{Bu}$ yönüyle de teleolojik olduğu söylenebilir.

Fakat verilen disiplin cezalarının eylemin amacına değil de sonucuna göre belirlendiği görülmektedir. Buna göre etik dışı eylemler için verilen cezaların deontolojik etik yaklaşımına değil, daha çok teleolojik etik yaklaşımının mantığına göre belirlendiği söylenebilir. Çünkü cezanın belirlenmesinde eylemin yapılış şekli ve amacından çok, eylemin sonucuna bakılması söz konusudur.

Disiplin cezalarını normatif etik yaklaşımları çerçevesinde ele aldığımızda yapılan eylemlerin deontolojik etik yaklaşımı ve erdem etiği yaklaşımlarına aykırı olduğu tespit edilmiştir. Etik dişı eylemlere ve verilen disiplin cezalar için alınan savunmalar topluca değerlendirildiğinde şu çarpıcı sonuca ulaşılmaktadır: Deontolojik ilkelerin ihlali daha çok teleolojik bakış açısı ve kaygısıyla yapılmaktadır. Bu durumda etik ikilemden en kolay çıkış yolu olduğu değerlendirilebilir. Aynı zamanda disiplin cezasına konu eylemlerin etik ikilemden çıkış argümanları kapsamında incelendiğinde (ki burada; aktörün eylemi gerçekleştirirken eylemini etik bir zemine oturtma ve etik davranma kaygısı taşıdığ varsayımıyla) yapılan eylemler teleolojik etik yaklaşımı açısından etik olarak değerlendirilebilecektir. Çünkü gerçekleştirilen eylemlerin sonucunda belli bir çıkar grubuna fayda sağlamaktadır. Dolayısıyla teleolojik etik yaklaşımının etiksel egoizm ve faydacılık varsayımları çerçevesinde incelenen eylemlerin etik davranışlar olarak nitelendirmek mümkündür. Fakat zorunlu meslek kurallarının ve disiplin yönetmenliğinin deontolojik yaklaşıma göre düzenlendiği göz ardı edilmemelidir. 


\section{KAYNAKLAR}

Baker C. R., Bedard. J. (2005). A Comparative Analysis of Regulation of Statutory Auditing in France, Canada and the United States. European Accounting Association Congress, (s. 1-29).

Baker, C. R., Bedard, J.\& Hauret, C. P. (2005). A Comparative Analysis of Regulation of Statutory Auditing in France, Canada and the United States. European Accounting Association Congress.

Banar, K., \& Aslan, Ü. (2009). Muhasebe Meslek Mensuplarının Almış Oldukları Disiplin Cezaları Üzerine Bir Araştırma (2000-2008 dönemi). Muhasebe ve Finansman Dergisi (MUFAD), 91-110.

Banks, S., \& Gallagher, A. (2009). Ethics in Professional Life: Virtues for Health and Social Care. NewYork: Palgrave Macmillan.

Bedard, J. (2001). The disciplinary process of the accounting profession: protecting the public or the profession? The Quebec experience. Journal of Accounting and Public Policy, 399-437.

Belak, J., \& Rozman, M. P. (2012). Business ethics from Aristotle, Kant and Mill's perspective. Kybernetes, 41(10), 1607 - 1624.

Bibus III, A. (tarih yok). Applying Approaches from Moral Philosophy, Especially Virtue Ethics, When Facing Ethical Dilemmas in Social Work.

Bowie, N. (1999). Business Ethics: A Kantian Perspective. Malden, Massachusetts: Blackwell Publishers.

Canning, M., \& O'Dwyer , B. (2001). Professional accounting bodies' disciplinary procedures: accountable, transparent and in the public interest? European Accounting Review, 10(4), 725-749.

Durkheim, E. (1986). Meslek Ahlakı (La Morale Professionnelle). İstanbul: Milli Eğitim Bakanlığı Yayınları.

Ekergil, V. (2016). Muhasebe Meslek Mensuplarının Etik-Disiplin İlişkisi ve Disiplin Cezası Analizi 1993-2015. Adıyaman Üniversitesi Sosyal Bilimler Enstitüsü Dergisi, 1(1), 363-402.

Frankel, M. (1989). Professional codes: Why, how, and with what impact? Journal of Business Ethics, 8(2-3), 109-115.

Garmilis, G., \& Stokes, L. (2007). Convergence of The Disciplinary Processes of Accounting Organizations? A Comparison Between The United States And France. American Accounting Association Annual Meeting, (s. 1-21). Chicago. 
Gül H. (2016). "Muhasebe Meslek Mensuplarının Almış Oldukları Disiplin Cezalarının Kayıtlı Olunan Oda, Unvan ve Cinsiyet Açısından Değişimi: 2001-2015 Dönemi", Adnan Menderes Üniversitesi Sosyal Bilimler Enstitüsü Dergisi, cilt.3, ss.44-62

Hartman, L., \& DesJardins, J. (2011). Business Ethics: Decision Making for Personal Integrity \& Social Responsibility (Cilt 2nd Edition). New York: McGraw-Hill.

Hoffman, W., \& Frederick, R. (1995). Business Ethics: Readings and Cases in Corporate Morality. McGraw-Hill Inc.

Horner, C., \& Westacott, E. (2000). Thinking Through Philosophy: An Introduction. Cambridge : Cambridge University Press .

Hursthouse , R. (1996). Normative Virtue Ethics . R. Crisp içinde, How Should One Live?: Essays on the Virtues (s. 19-37). New York: Oxford University Press.

Hursthouse, R. (1991). Virtue Theory and Abortion. Philosophy \& Public Affairs, 20(3), 223246.

Jonsson, P. (2011). On utilitarianism vs virtue ethics as foundations of economic choice theory. Humanomics, 27(1), 24 - 40.

Kant, I. (1785). Fundamental Principles Of The Metaphysic Of Morals. Çev: Thomas Kingsmill Abbott: An Electronic Classics Series Publication.

Kant, I., \& Gregor, M. (1998). Groundwork of the Metaphysics of Morals. Cambridge, UK: Cambridge University Press.

Kart, B. (2006). Deontolojist ve Teleolojist Kuramlar İkileminde "Erdem Etiği". Ankara: Hacettepe Üniversitesi Sosyal Bilimler Enstitüsü.

Lee, T. (1995). The professionalization of accountancy: A history of protecting the public interest in a self-interested way. Accounting, Auditing \& Accountability Journal, 8(4), 48-69.

Mitchell, A., Puxty, T., Sikka, P., \& Wiltmot, H. (1994). Ethical Statements as Smokescreens for Sectional Interests: The Case of the UK Accountancy Profession. Journal of Business Etkics, 13, 39-51.

Parker, L. (1987). An Historical Analysis of Ethical Pronouncements and Debate in the Australian Accounting Profession. Abacus, 23(2), 122-138.

Platon. (1982). Devlet. Çeviren: S. Ryuboğlu, M. A. Cimcoz: Türkiye İş Bankası Kültür Yayınları.

Pops, G. (2000). A teleological Approach to Administrative Ethics. T. Cooper içinde, Handbook of Administrative Ethics (s. 195-206). New York: Marcel Dekker Inc.

Reamer, F. (2013). Social Work Values and Ethics. New York: Columbia University Press. 
Serbest Muhasebeci Mali Müşavirler ve Yeminli Mali Müşavirlerin Mesleki Faaliyetlerinde Uyacakları Etik İlkeler Hakkında Yönetmelik, Madde 1. (2007).

Svara, J. (2007). The Ethics Primer for Public Administrators in Government and Nonprofit Organizations. Jones \& Bartlett Publishers.

Ünder, H. (2013). İş Etiği. Eskişehir: Anadolu Üniversitesi.

West, J., \& Berman, E. (2006). The Ethics Edge. Washington, DC: International City/County Management Association.

Whetstone, J. (2001). How Virtue Fits Within Business Ethics. Journal of Business Ethics, 33, 101-114.

Yaşar, A. (2016). "Muhasebe Meslek Mensuplarının Mesleki Kurallara Duyarlılığının Cinsiyet Yönünden Karşılaştırılması: 2001-2015 Disiplin Cezaları Yönünden Bir İnceleme", Journal of Human Sciences, 13/2, 3413-3428

aktaran Güllüce, V. (2007). İnsana verilen özellikler, onun yeniden diriltilmesi gerektiğine ve ebedi hayatın varlığına delil olabilir mi? . Erişim: 25 Ocak 2014 tarihinde Sorularla İslamiyet: http://www.sorularlaislamiyet.com/article/9678/insana-verilen-ozellikleronun-yeniden-diriltilmesi-gerektigine-ve-ebedi-hayatin-varligina-delil-olabilir-mi.html adresinden alındı

3568 Sayılı. (1989). Serbest Muhasebeci Mali Müşavirlik ve Yeminli Mali Müşavirlik Kanunu.

Different Kinds of Ethics. Erişim: 25 Ocak 2017 tarihinde http://www3.sympatico.ca/saburns/pg0405.htm adresinden alınd1

Ethics Theories. Erişim: 02Eylül 2016 tarihinde Chegg Study: http://www.chegg.com/homework-help/definitions/ethics-theories-3 adresinden alındı 
